\title{
Assessment of urban river water quality and developing strategies for phosphate removal from water and wastewaters: Integrated monitoring and mitigation studies
}

\author{
Harsha Mahadevan $^{1,3} \cdot$ K. Anoop Krishnan ${ }^{1}$ (D) · Renjith R. Pillai ${ }^{1,2}$ - Sandhya Sudhakaran ${ }^{1,3}$
}

Received: 18 December 2019 / Accepted: 18 March 2020 / Published online: 28 March 2020

(c) Springer Nature Switzerland AG 2020

\begin{abstract}
In this work, the water quality status of the surface water that lies around the Karamana River basin, Trivandrum urban area, was studied on the basis of the water quality index (WQI) method. The eutrophic condition of the basin is revealed, and proper mitigation strategy was adopted for the removal of phosphate species using pillared clay materials. Proper sampling was carried out in the urban rivers, and various physico-chemical parameters for evaluating the quality of water were analysed. WQI values obtained for these riverine systems are in the range 317.7-3005.1, indicating that the water is not suitable without treatment for any domestic activities. Also, phosphate ions in the range 1.98-20.52 mg/L reflect the dominance of phosphate species in surface water. A proper mitigation strategy was adopted for the selective removal of phosphate ions using adsorption technique by using zirconium-pillared bentonite clay (ZPBC) prepared by the stirring-ageing technique. The batch adsorption experiment performed on simulated phosphate solution shows that for $2.0 \mathrm{~g} / \mathrm{L}$ of ZPBC a maximum phosphate adsorption capacity of $35.71 \mathrm{mg} / \mathrm{g}$ was achieved in $30 \mathrm{~min}$ at pH 3.0 . The data obtained were used to study models in kinetics and isotherm. The reusability of spent ZPBC for five continuous cycles without major loss in adsorption capacity using $0.025 \mathrm{M} \mathrm{Na}_{2} \mathrm{CO}_{3}$ extractant was proved from the desorption study. A single-stage reactor was also designed from the isotherm data and proved to be effective. The applicability of the adsorbent towards phosphate anions was successfully checked in the laboratory using surface water collected and found that the complete removal of phosphate was achieved using 6.0, 8.0 and 10.0 g/L of ZPBC.
\end{abstract}

Keywords Urban area - Water quality index · Mitigation · Phosphate · Adsorption · Desorption

\section{Introduction}

Urban river water chemistry is a principal component of metropolitan areas as it maintains the survival of the urban ecosystem through receiving and flushing out mechanism. But the discharge of municipal sewage and industrial effluents beyond the controlling level cause harmful effects on the lives of city dwellers. The presence of pollutants in the aquatic environment inhibits the penetration of light into the water bodies, creating an anoxic condition and destroying flora-fauna of the aquatic environment [1-3]. Thus, using water quality index (WQI) with international standard limits we can determine the water chemistry and hence the status of water pollution in these areas $[4,5]$. WQI method based on different modes of calculations has been widely developed by many authors to assess water

Electronic supplementary material The online version of this article (https://doi.org/10.1007/s42452-020-2571-0) contains supplementary material, which is available to authorized users.

K. Anoop Krishnan, sreeanoop@rediffmail.com; sree.anoop@ncess.gov.in | ${ }^{1}$ Hydrological Processes Group, National Centre for Earth Science Studies (NCESS), Akkulam, Trivandrum 695011, India. ${ }^{2}$ Department of Chemistry, Mar Ivanios College, Nalanchira, Trivandrum, India. ${ }^{3}$ University of Kerala, Trivandrum, India. 
quality of rivers all around the world like Hooghly River in India, Yellow River in China, Suquia River in Argentina, Amazonian rivers in Brazil and Beheshtabad River in Iran [6-10]. Thus, from the outcome of WQI calculations, the public and government can easily understand the healthiness of the river and also can take suitable measures regarding human intervention and surface water preservation in the area, particularly in a developing country like India, where rivers are considered as sacred.

The occurrence of excessive nutrients ( $N$ and $P$ ) in rivers is mainly due to anthropogenic activities which may lead to eutrophication, causes uncontrolled algal growth, ineffective environment for fish and depletion of dissolved oxygen and affects the biodiversity; in overall, it may lead to the extinction of a variety of species [11, 12]. Phosphorus can be brought to minimal concentration than nitrogen, so in order to control eutrophication special emphasis is given to phosphorus than nitrogen $[13,14]$. Phosphorus compounds such as inorganic phosphate, pyrophosphate, phosphodiesters and organic phosphate esters are converted to orthophosphate chemically or enzymatically in an aqueous environment. So, orthophosphate is the only prominent form that could be utilized by prokaryotic and eukaryotic organisms $[15,16]$. For the treatment of wastewater, various techniques are reported by researchers, such as adsorption, oxidation, flocculation-coagulation, membrane filtration and biological treatment $[17,18]$. Among them, adsorption is an effective technique for the removal of pollutants because of low cost, minimal sludge production, recovery of adsorbent and high efficiency [1, $2,19]$. So we have opted for an adsorption technique for the complete removal of phosphate in river water [20]. Bentonite is an easily available 2:1 natural clay mineral with low cost and non-toxicity and is widely used for nutrient removal studies because of its high anion exchange capacity. It has an octahedral layer that is sandwiched between two tetrahedral layers with a negative charge on its surface which is mainly balanced by $\mathrm{Na}^{+}$and $\mathrm{Ca}^{2+}$, which are exchangeable with pillared cations resulting in the increase in efficiency in phosphate removal [21,22]. So by modifying the precursor bentonite, the efficiency of adsorption towards phosphate could be increased.

The systematic monitoring of water quality of an urban river basin followed by mitigation of a specific anion in the presence of other co-existing ions is not reported in any of the research work related to water chemistry. The aim of the present study is to explore the eutrophic condition of the surface water in the urban area of Trivandrum using the water quality index method followed by adsorption of phosphate anions present in the riverine system using pillared clay. The mitigation study for phosphate removal on these urban rivers was carried out using the adsorbent ZPBC. The preparation of the adsorbent ZPBC and its characterization is reported by our group [23]. In this work, adsorption conditions for simulated phosphate solutions such as contact time with various concentrations 15,25 , 50 and $100 \mathrm{mg} / \mathrm{L}$ and with different temperatures 15, 25 and $35^{\circ} \mathrm{C}$ were optimized to study various kinetic and isotherm models. The spontaneity of the adsorption process was investigated using thermodynamic studies. Finally, the adsorbent was effectively applied for the removal of phosphate in riverine samples collected during fieldwork.

\section{Materials and methods}

\subsection{Monitoring studies}

\subsubsection{Study area and sampling locations}

Trivandrum, the capital city of Kerala, situated between $8^{\circ}$ $17^{\prime}$ and $8^{\circ} 54^{\prime} \mathrm{N}$ latitude and $76^{\circ} 41^{\prime}$ and $77^{\circ} 17^{\prime} \mathrm{E}$ longitude is blessed with three major rivers. This study is mainly concentrated on the highly populated urban areas of this district, where the entire Karamana River basin lies. Karamana River $(67 \mathrm{~km})$, the major river in this basin, has its origin from Chemmunji Motta of Western Ghats, recognized as one among the world's eighth hottest spots by the UNESCO world heritage due to its rich biodiversity. This river is the major surface water source for the Trivandrum water supply scheme. The best-known tributary of Karamana River is Killiyar which is also part of the monitoring study. Another major canal residing in this basin is Parvathy Puthanar (part of Travancore-Shoranur Canal) having a length of $16.5 \mathrm{~km}$ stretching from Akkulam-Veli (N) to Kovalam (S) of the city. This canal is also taken for the water quality study as the sewage is dumped into this canal from various small drains present in the city. About $70 \%$ of the sewage from urban areas is conveyed to the sewage treatment plant at Muttathara, but the remaining part is dumped into this riverine system that causes severe problems for the flora and fauna of the aquatic system. The sampling sites were identified and recorded using a portable GPS (Make: Garmin, Model: Montana 650, USA), and the locations from which samples have been collected are shown in Fig. $\mathrm{S} 1$.

\subsubsection{Field work details}

The samples were collected during the post-monsoon season (November 2018) from two rivers each namely Karamana (stations 1, 2 and 3), Killiyar (stations 4, 5 and 6) and Parvathy Puthanar canal (stations 7,8 and 9) from about $0.6 \mathrm{~m}$ below the water surface. The parameters such as water temperature $\left({ }^{\circ} \mathrm{C}\right), \mathrm{pH}$, electrical conductivity (EC), total dissolved solids (TDS) and dissolved oxygen 
(DO) were measured in situ without pretreatment using a calibrated transportable water quality equipment (Make: Eutech, Model: Aquaread 1000 D, Germany). Before the laboratory analysis of chloride $\left(\mathrm{Cl}^{-}\right)$, sulphate $\left(\mathrm{SO}_{4}{ }^{2-}\right)$ and bicarbonate $\left(\mathrm{HCO}_{3}{ }^{-}\right)$, phosphate $\mathrm{PO}_{4}{ }^{3-}-\mathrm{P}$, ammonia $\left(\mathrm{NH}_{4}{ }^{+}-\mathrm{N}\right)$ and nitrate $\left(\mathrm{NO}_{3}{ }^{-}-\mathrm{N}\right)$ water samples were filtered using $0.45-\mu \mathrm{m}$ Whatman TM uniflo PVDF sterile disposable syringe filters and preserved in an airtight 1-L acid-cleaned sealed polyethylene bottle (PE). Before the collection of water samples in PE bottles, they were thoroughly rinsed with distilled water. All the field samples were preserved in ice bags to maintain ambient conditions until they get analysed. The method adopted for the determination of chemical parameters of the samples is taken from procedures mentioned in American Public Health Association [24]. The chemicals required for the determination of chemical parameters were purchased from E. Merck, India. The experiments and calculations were completed within a week, and the entire analysis was carried out in triplicate.

\subsubsection{Examination of the quality of water by WQI method}

The physico-chemical parameters such as $\mathrm{pH}, \mathrm{EC}, \mathrm{DO}, \mathrm{TDS}$, $\mathrm{Cl}^{-}, \mathrm{SO}_{4}{ }^{2-}, \mathrm{NO}_{3}{ }^{-}-\mathrm{N}, \mathrm{PO}_{4}{ }^{3-}-\mathrm{P}$ and $\mathrm{NH}_{4}{ }^{+}-\mathrm{N}$ were used for the calculation of WQI. Each parameter was given the weightage $\left(w_{i}\right)$ value from 1 to 5 depending upon their importance in the surface water (Table S1).

$\mathrm{DO}, \mathrm{EC}$ and nutrient parameters such as $\mathrm{PO}_{4}{ }^{3-}-\mathrm{P}$ and $\mathrm{NO}_{3}{ }^{-}-\mathrm{N}$ were given weightage $5\left(w_{i}=5\right)$. DO is needed for the survival of flora-fauna of the aquatic system. The decrease in DO value is an indication of polluted water, and there is a high possibility of eutrophication. The eutrophic condition of surface water mainly concentrates on the amount of $\mathrm{PO}_{4}{ }^{3-}-\mathrm{P}$ and $\mathrm{NO}_{3}{ }^{-}-\mathrm{N}$ present. These two anions from fertilizers and detergents when discharged into surface water cause the growth of aquatic plants and depletion of $\mathrm{DO}$, finally affecting the water quality by causing eutrophication. EC is an indirect measure of total dissolved salts and also confirms the presence of inorganic pollutants (industrial effluents) present in surface water. Thus, EC indicates the state of surface water, i.e. whether the water system is suitable for the survival of aquatic life [25]. Hence, we assigned these three parameters a weightage 5 .

The reason for assigning the weightage 4 for parameters $\mathrm{pH}, \mathrm{NH}_{4}{ }^{+}-\mathrm{N}$, TDS and $\mathrm{SO}_{4}{ }^{2-}$ is as follows: the acidity or alkalinity of water can be understood by the measurement of $\mathrm{pH}$. The flow of fertilizers that contain nutrients, mainly phosphate and nitrate, into the surface water results in higher $\mathrm{pH}$ and proliferation of algal growth. Conversely, the physiological functions of aquatic life are affected at low $\mathrm{pH}$ [26]. So pH indicates the state of water. The concentration of $\mathrm{NH}_{4}^{+}-\mathrm{N}$ in the surface water depends upon
$\mathrm{pH}$ and temperature. Although aquatic organisms excrete ammonia, the high concentration of $\mathrm{NH}_{4}^{+}-\mathrm{N}$ in the aquatic system occurs due to the discharge of domestic sewage and industrial effluents [27]. The source of $\mathrm{SO}_{4}{ }^{2-}$ in urban surface water might be from sulphate-bearing fertilizers, sulphuric salts in domestic sewage and also by weathering of soils. Moreover, sulphates form strong acids that change the $\mathrm{pH}$ of water [28]. The high value of TDS causes an increase in salinity, changes the ionic composition of water, eliminates less tolerant aquatic species and thus overall affects the quality of surface water [29]. Chlorides $\left(\mathrm{Cl}^{-}\right)$are usually combined with sodium and to a lesser extent with calcium, magnesium and potassium, making them a stable component in water. The increase in the content of $\mathrm{Cl}^{-}$causes acidification of streams and affects the reproduction capability of aquatic plants and animals [30]. Thus, it affects the water quality and given a weightage 3. For the WQI calculation, the standard values of surface water were taken from various studies [31-33]. The relative weight $\left(W_{i}\right)$, quality rating $\left(q_{i}\right)$ and WQI are computed using the following equations [34]:

The relative weight and quality rating equation:

$W_{i}=\frac{w_{i}}{\sum_{i=1}^{n} w_{i}}$

and

$q_{i}=\frac{C_{i}}{S_{i}} \times 100$

Sub-index equation:

$\mathrm{SI}_{i}=W_{i} \times q_{i}$

Water quality index equation:

$\mathrm{WQI}=\sum_{i=1}^{n} \mathrm{SI}_{i}$

where $n$ represents the number of parameters, $w_{i}$ is the weight of each parameter, $C_{i}$ is the concentration of the $i$ th parameter for each sampling site, $S_{i}(\mathrm{mg} / \mathrm{L})$ is the standard for surface water, and $\mathrm{SI}_{i}$ is the sub-index of the $i$ th parameter.

\subsection{Mitigation studies}

\subsubsection{Materials}

The adsorbent, bentonite clay (AR grade) was procured from Sigma-Aldrich, India, and for pillaring process Emsure-grade zirconium (IV) oxychloride was purchased from Merck, India. For the contact time and temperature studies, simulated stock solution of phosphate 
(1000 mg/L) was prepared using $\mathrm{KH}_{2} \mathrm{PO}_{4}$ purchased from Merck, India. For the spectrometric determination of phosphate, E. Merck chemicals were used (ascorbic acid, ammonium heptamolybdate tetrahydrate, potassium antimony (III) oxide tartrate hemihydrates).The desorption studies were carried out using $\mathrm{NaOH}, \mathrm{Na}_{2} \mathrm{CO}_{3}, \mathrm{HCl}$ and $\mathrm{NaHCO}_{3}$ supplied from Merck, India. All chemicals used were AR grade, and the reagents were prepared using Milli-Q water.

\subsubsection{Procedure adopted for ZPBC—zirconium-pillared bentonite clay}

The successful synthesis of ZPBC and the detailed procedure carried out using the stirring-ageing technique are reported in our previous work [23]. A brief description of the procedure adopted for pillared clay preparation is as follows: about $4 \mathrm{~mL} / \mathrm{min}$ of 0.2 zirconium oxychloride $(500 \mathrm{~mL})$ is added dropwise to an RB flask containing the stirring solution of sodium bentonite $(12 \mathrm{~g})$ kept at room temperature. The process is continued for $10 \mathrm{~min}$, and after that $40 \mathrm{~mL}$ of the remaining zirconium solution was added to the stirring mixture as described above and kept for ageing for another $10 \mathrm{~min}$. The same slot addition of aliquot and ageing is continued until $6 \mathrm{~h}$ and $25 \mathrm{~min}$ is reached. Finally, the mixture is stirred vigorously for $2 \mathrm{~h}$ followed by 4-h ageing. After checking the $\mathrm{pH}$, the solution was centrifuged and the residue part is washed with deionized water to free from chloride. The material is then dried at $80^{\circ} \mathrm{C}$, milled, labelled as ZPBC and kept in the bottle for further studies. The pillaring of $\mathrm{Zr}$ onto precursor clay is confirmed from various spectroscopic techniques that were reported in our work mentioned above.

\subsubsection{Batch adsorption experiments}

The effect of contact time (10, 20, 30, 40 and $50 \mathrm{~min})$, initial phosphate concentrations $(15,25,50$ and $100 \mathrm{mg} / \mathrm{L}$ ) and temperatures $\left(15,25\right.$ and $\left.35^{\circ} \mathrm{C}\right)$ for the adsorption of phosphate were studied by taking $2.0 \mathrm{~g} / \mathrm{L}$ of ZPBC in Erlenmeyer flasks optimized at $\mathrm{pH} 3.0$ using $0.1 \mathrm{M} \mathrm{NaOH}$ and $0.1 \mathrm{M} \mathrm{HCl}$. Then, treated solutions with varying different concentrations of phosphate were analysed using ultraviolet-visible NIR spectrophotometer (Make: Shimadzu, Model: UV-3600 plus, Germany) measured at a wavelength of $880 \mathrm{~nm}$ by ammonium molybdate method [24]. The amount of phosphate adsorbed was calculated by using the following equation:

$q=\frac{\left[\left(C_{0}-C_{\mathrm{A}}\right)\right] V}{m}$

where $C_{0}$ is the initial phosphate concentration and $C_{A}$ is the concentration of phosphate at equilibrium in $\mathrm{mg} / \mathrm{L}, V$ is the volume of phosphate solution in $\mathrm{mL}$, and $\mathrm{m}$ is the mass of the adsorbent in grams.

The reusability of the adsorbent (ZPBC) was investigated by conducting desorption studies. The phosphateloaded ZPBC was centrifuged and washed thoroughly with Milli-Q water to remove any unabsorbed phosphate ions. The desorption experiments were carried out using $\mathrm{NaOH}$, $\mathrm{Na}_{2} \mathrm{CO}_{3}, \mathrm{HCl}$ and $\mathrm{NaHCO}_{3}$ as desorption agents. Among them, $\mathrm{Na}_{2} \mathrm{CO}_{3}$ was found to be more effective and was selected for further studies. The regenerated clay was used for adsorption, and the sorption experiment was continued for five cycles.

The effect of the adsorbent dosage (2.0, 4.0 6.0, 8.0 and $10.0 \mathrm{~g} / \mathrm{L}$ ) was carried out for the phosphate removal studies. The filtered riverine samples collected during the field work were used for the dosage experiment. The entire test was conducted in duplicate, and the mean values are reported.

\section{Results and discussion}

\subsection{Monitoring studies}

\subsubsection{Hydrochemical characteristics}

Physico-chemical parameters reflect the surface water quality, and the result obtained during analysis is shown in Table 1. The surface water temperature varied from 29.1 to $31.4^{\circ} \mathrm{C}$ during the sampling period. The acidity and basicity of the water are well understood by $\mathrm{pH}$ studies. In the present study, it can be seen that $\mathrm{pH}$ values varied from 7.01 to 8.71 from stations 1 to 9 . A wide variation for DO values was obtained for all the stations during in situ measurements. The lower DO was obtained for stations 7,8 and 9 with values ranging from 3.01 to $3.32 \mathrm{mg} / \mathrm{L}$. The DO concentration obtained for the canal is very much lower, i.e. below the standard limit ( $5 \mathrm{mg} / \mathrm{L}$ ) of WHO (2011) for drinking purposes and also below the standard limit of surface water $(6 \mathrm{mg} / \mathrm{L})$. Sewage channel is joining this canal at different points leading to nutrient load, weed growth and a decrease in DO. Stations 7, 8 and 9 reported a high value of EC compared to all other stations and are found to be above the surface water standard limit $(400 \mu \mathrm{S} / \mathrm{cm})$. The high value of EC in the canal indicates a high degree of pollution due to the dumping of sewage waste. TDS values for Karamana River and Killiyar were within the permissible limit $(500 \mathrm{mg} / \mathrm{L})$ of WHO (2011), but in the case of Parvathy Puthanar, values are very high (1782.01 to $1987.30 \mathrm{mg} / \mathrm{L}$ ). The values are higher than the surface water standard $(1200 \mathrm{mg} / \mathrm{L})$. The TDS level in Parvathy Puthanar is high due to septic and domestic sewage waste present in the water. The bicarbonate levels from stations 1-6 were 


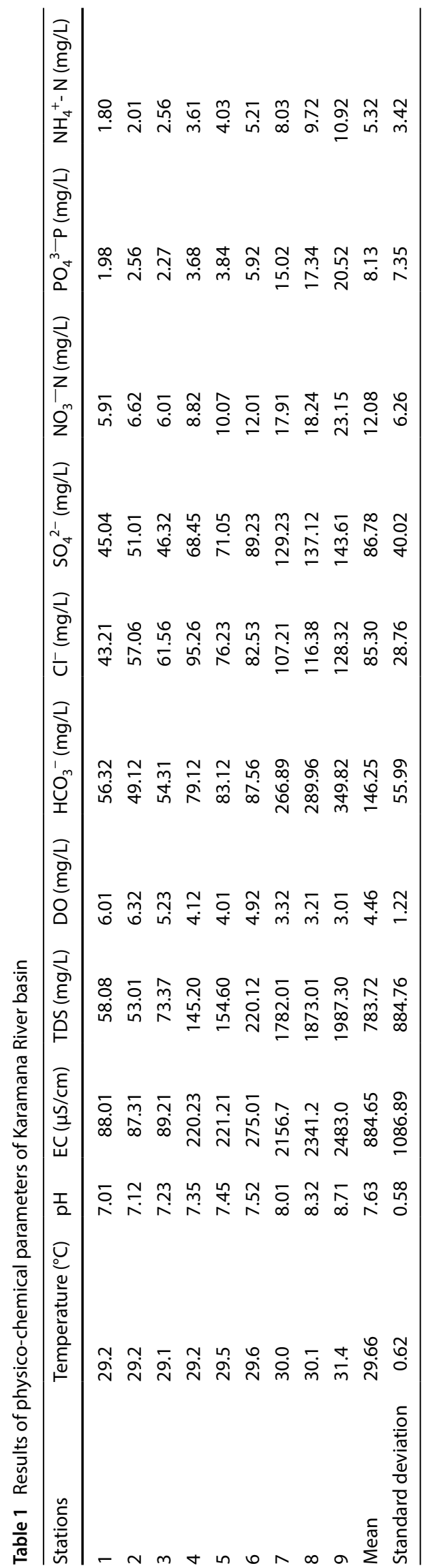

within the permissible limit of $120 \mathrm{mg} / \mathrm{L}$ of (WHO 2011) for drinking purposes but slightly high values for other stations. The concentrations of $\mathrm{Cl}^{-}$and $\mathrm{SO}_{4}{ }^{2-}$ varied from 43.21 to $128.32 \mathrm{mg} / \mathrm{L}$ and 45.04 to $143.61 \mathrm{mg} / \mathrm{L}$, respectively, indicating that the values are within the standard limit $(250 \mathrm{mg} / \mathrm{L})$. The major nutrients such as ammonia $\left(\mathrm{NH}_{4}{ }^{+}-\mathrm{N}\right)$, phosphate $\left(\mathrm{PO}_{4}{ }^{3-}-\mathrm{P}\right)$ and nitrate $\left(\mathrm{NO}_{3}{ }^{-}-\mathrm{N}\right)$ also affect the quality of water, and their limit beyond permissible limits causes serious health problems in rivers. Among the nutrient parameters, mainly phosphate is easily absorbed by plants, causing increased productivity of phytoplanktons resulting in eutrophication, and finally the entire area becomes deserted [35]. $\mathrm{PO}_{4}{ }^{3-}-\mathrm{P}$ values for all the stations ranged from 1.98 to $20.52 \mathrm{mg} / \mathrm{L}$ with the maximum in stations 7,8 and 9 . In general, all the stations $\mathrm{PO}_{4}{ }^{3-}-\mathrm{P}$ values were found to be exceeding the permissible limit ( $>0.1 \mathrm{mg} / \mathrm{L}$ ) prescribed by WHO (2011) and surface standard limit set by researchers. Moreover, it is reported that for phosphate values greater than $1.0 \mathrm{mg} / \mathrm{L}$, there is a high risk of eutrophication. The values for $\mathrm{NO}_{3}{ }^{-}-\mathrm{N}$ and $\mathrm{NH}_{4}{ }^{+}-\mathrm{N}$ varied from 5.91 to $23.15 \mathrm{mg} / \mathrm{L}$ and 1.80 to $10.92 \mathrm{mg} / \mathrm{L}$, respectively, having high values for Parvathy Puthanar. $\mathrm{NO}_{3}{ }^{-}-\mathrm{N}$ values for stations $1-5$ were within $10 \mathrm{mg} / \mathrm{L}$ as per surface water standards, whereas $\mathrm{NH}_{4}{ }^{+} \mathrm{N}$ was higher for all stations with values above the permissible limit $(0.5 \mathrm{mg} / \mathrm{L})$. Higher ammonia creates an oxygen demand in these stations and also releases nitrous oxide gas produced as a result of the denitrification process. The trend obtained from the nutrient analysis is as follows: $\mathrm{PO}_{4}{ }^{3-}-\mathrm{P}>\mathrm{NH}_{4}{ }^{+}-\mathrm{N}>\mathrm{NO}_{3}{ }^{-}-\mathrm{N}$. The level of nutrients, especially phosphate present in the riverine systems, is high due to the dumping of sewage wastes, both solid and liquid from small drainage channels or from people residing banks of rivers. The phosphate level is tremendously high in Parvathy Puthanar, indicating the disappearance of the canal in the nearby future due to eutrophication. So proper treatment strategies must be introduced for saving the rivers and canal from nutrient pollution, particularly from phosphate.

\subsubsection{Interpretation of WQI}

The WQI value obtained from the calculations for nine stations is presented in Table 2 . The results showed that WQI values are varying for different sampling sites. WQI values calculated for the Karamana River and Killiyar are in the range 317.7-370.71 and 581.62-910.96, respectively. For Parvathy Puthanar, WQI values $>2200$. The surface water standard was considered for the calculation of the water quality index method. In other studies, WQI is calculated on the basis of the drinking water standard. So the comparison of our results with them is not possible. In some places of urban areas, people use water directly for bathing 
Table 2 WQI values obtained for post-monsoon season from rivers and canal

\begin{tabular}{llllllllll}
\hline Stations & 1 & 2 & 3 & 4 & 5 & 6 & 7 & 8 & 9 \\
\hline WQI values & 317.70 & 326.84 & 370.71 & 581.62 & 613.91 & 910.96 & 2217.87 & 2558.82 & 3005.12 \\
\hline
\end{tabular}

and domestic purposes. Even if we take the drinking water standard limit of WHO, WQI values obtained will be very higher indicating unsuitability in drinking purposes. Most of the areas' river water is used after pretreatment. However, the concentration of ions, especially nutrient anions, in all the stations obtained is very high when compared to the surface water standard limit and also the drinking water standard limit. The high phosphate level indicates a great threat to the current aquatic environment, and this will definitely affect the existence of the future riverine systems. So a proper mitigation method should be adopted at the earliest for the preservation of the aquatic system.

\subsection{Mitigation studies}

\subsubsection{Effect of contact time and temperature}

A maximum of $92.4 \%$ phosphate removal was achieved at $\mathrm{pH} 3.0$ for $15 \mathrm{mg} / \mathrm{L}$ phosphate solution concentration using an adsorbent (ZPBC) dose of $2.0 \mathrm{~g} / \mathrm{L}$. Further increasing the $\mathrm{pH}$, adsorption decreases appreciably. At $\mathrm{pH}$ 3.0, the surface of the pillared clay becomes more positive that tends to attract $\mathrm{H}_{2} \mathrm{PO}_{4}{ }^{-}$from phosphate solution resulting in effective adsorption. Figure 1a represents the contact time required for various concentrations 15, 25, 50 and $100 \mathrm{mg} / \mathrm{L}$ to reach equilibrium using the above-optimized condition. As contact time proceeds, the amount of phosphate adsorbed increases and reaches equilibrium within $30 \mathrm{~min}$. The maximum $q_{\mathrm{e}}$ values obtained are 6.97, $11.30,19.22$ and $19.32 \mathrm{mg} / \mathrm{g}$ for various concentrations $15,25,50$ and $100 \mathrm{mg} / \mathrm{L}$ within $30 \mathrm{~min}$. As contact time proceeds further, there is no appreciable change in phosphate adsorption from the solution by the adsorbent due to the unavailability of the bare clay surface for the uptake of phosphate molecules. The fast adsorption rate is very crucial and important for the practical application of the adsorbent [36]. The influence of temperature on the interaction between ZPBC and phosphate was studied using three different temperatures 15,25 and $35^{\circ} \mathrm{C}$ under the optimized condition (Fig. 1b). It can be seen that as the temperature rises the amount of phosphate adsorption reached $34.83 \mathrm{mg} / \mathrm{g}$ at $35^{\circ} \mathrm{C}$. A possible explanation for the increase in the amount of adsorption at higher temperatures can be due to the increase in active sites on the adsorbent surface for adsorption and also rise in the temperature increases the mobility rate of phosphate species onto the surface of the adsorbent. Hence, it is assumed that adsorption is an endothermic one [37].

\subsubsection{Adsorption kinetics, isotherm and thermodynamic studies}

To predict the adsorption chemistry of ZPBC with phosphate (physisorption or chemisorption), the
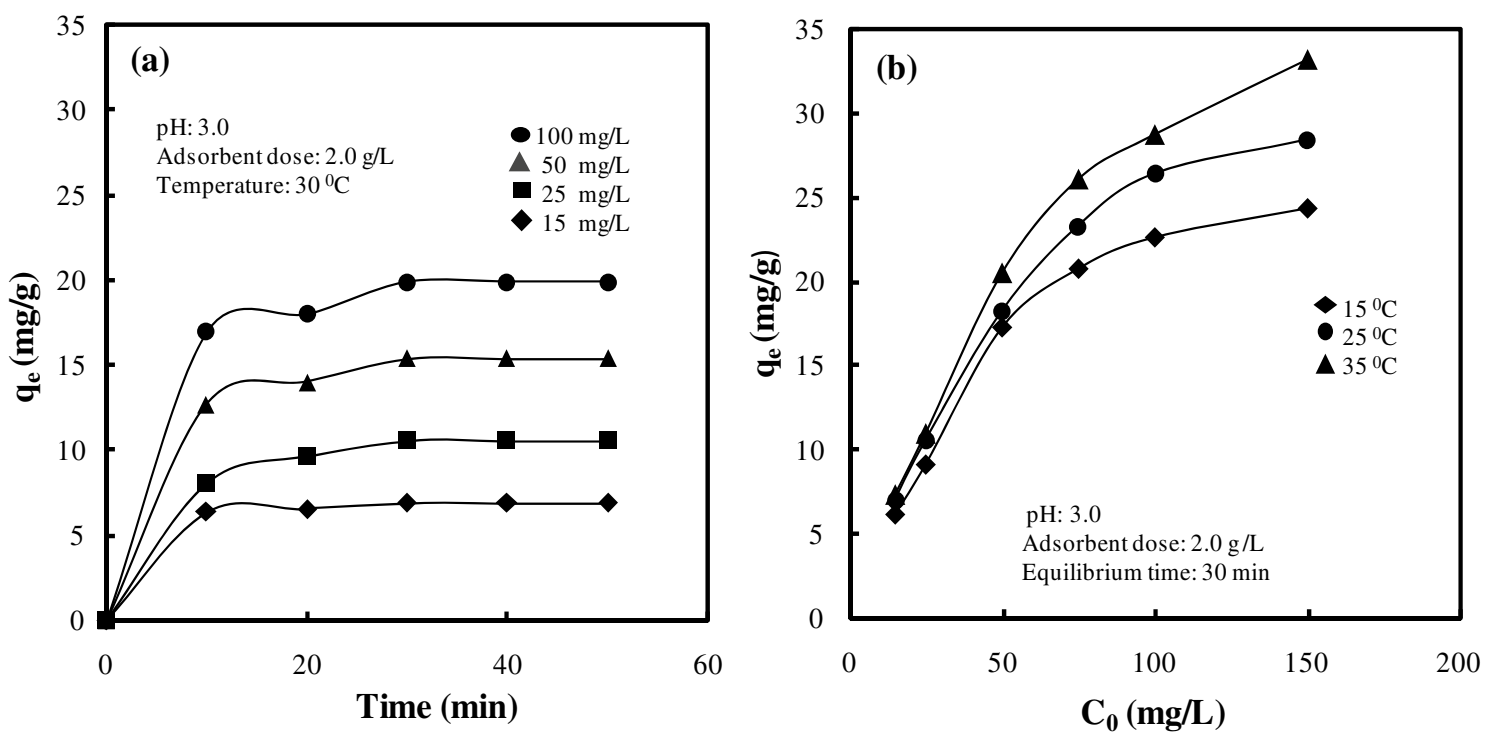

Fig. 1 Effect of a contact time and $\mathbf{b}$ temperature on phosphate adsorption onto ZPBC 
experimental data obtained from contact time for various initial concentrations $15,25,50$ and $100 \mathrm{mg} / \mathrm{L}$ were used for the calculation of using two prominent models: pseudo-first-order and pseudo-second-order [38, 39], and the equation is as follows:

Lagergren pseudo-first-order equation:

$\log \left(q_{\mathrm{e}}-q_{t}\right)=\log q_{\mathrm{e}}-\frac{k_{1} t}{2.303}$

Mckay and Ho pseudo-second-order equation: $\frac{t}{q_{t}}=\frac{1}{k_{2} q_{\mathrm{e}}^{2}}+\frac{t}{q_{\mathrm{e}}}$

where $k_{1}(1 / \mathrm{min})$ and $k_{2}(\mathrm{~g} / \mathrm{mg} / \mathrm{min})$ are the pseudo-firstorder and pseudo-second-order rate constants for an amount of phosphate adsorbed at equilibrium $q_{\mathrm{e}}$ and $q_{\mathrm{t}}$ in $\mathrm{mg} / \mathrm{g}$ at time $t(\mathrm{~min})$, respectively. The values for $k_{1}$ and $q_{\mathrm{e}}$ were calculated from the slope and intercept by plotting $\log \left(q_{\mathrm{e}}-q_{t}\right)$ against $\mathrm{t}$ (Fig. 2a), whereas $k_{2}$ and $q_{\mathrm{e}}$ were calculated from the slope and intercept of the plot $t / q_{t}$ against $t$ (Fig. 2b). Table 3 clearly shows the pseudo-second-order with higher $R^{2}$ value $(0.998,0.985,0.984,0.992)$ indicating chemisorption as the rate-limiting step in the
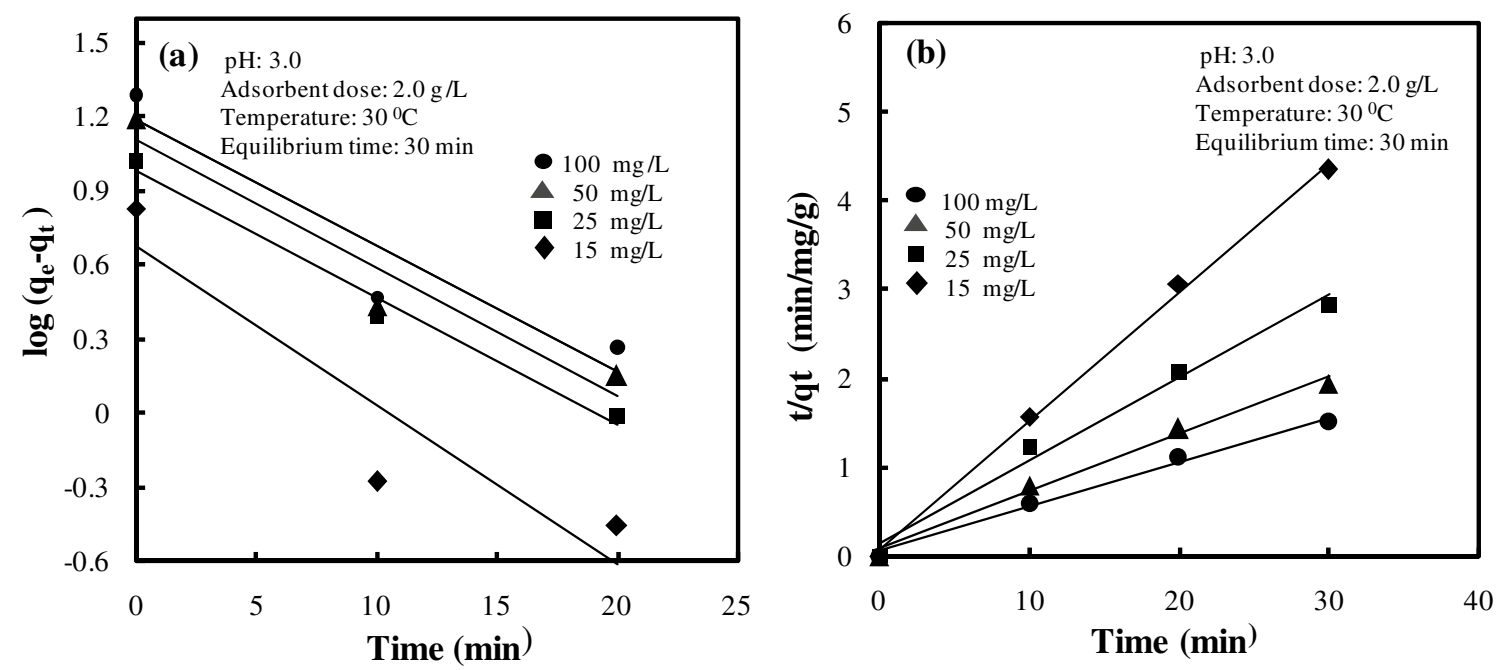

Fig. 2 a Pseudo-first-order, b pseudo-second-order kinetic plots for the adsorption of phosphate onto ZPBC

Table 3 Kinetic and isotherm parameters for the adsorption of phosphate onto ZPBC

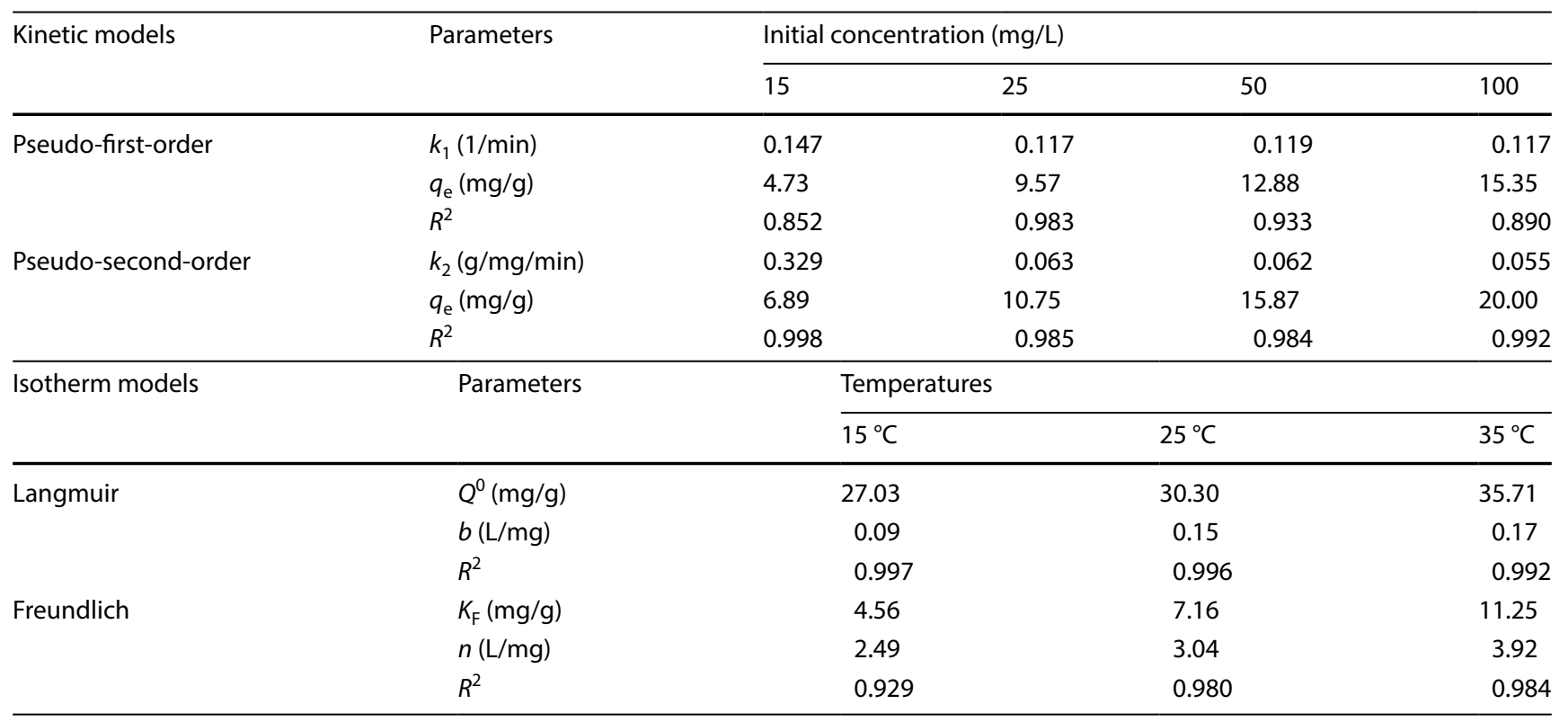


phosphate adsorption process [40]. The rate constant $k_{2}$, for the adsorption of phosphate, was found to decrease for various initial phosphate concentrations $(15 \mathrm{mg} / \mathrm{L}$ to $100 \mathrm{mg} / \mathrm{L}$ ). By obtaining pseudo-second-order kinetics, it is confirmed that sorption onto ZPBC proceeds by electrostatic interaction between adsorbent and adsorbate. Similar results are obtained for phosphate removal using other adsorbents [41, 42].

The adsorption capacity of the adsorbent is mathematically calculated by using two common models, Langmuir [43] and Freundlich [44], with the help of isotherm data for various temperatures 15,25 and $35^{\circ} \mathrm{C}$. Langmuir isotherm occurs on the homogenous adsorbent surface indicating monolayer adsorption, but for Freundlich isotherm adsorption occurs on heterogeneous surfaces and more possibly adsorption is a multilayered one $[45,46]$. The equations of these two models are given in Eqs. 8 and 9:

Langmuir equation:

$\frac{C_{\mathrm{e}}}{q_{\mathrm{e}}}=\frac{1}{b Q^{0}}+\frac{C_{\mathrm{e}}}{Q^{0}}$

Freundlich equation:

$\log q_{\mathrm{e}}=\log K_{\mathrm{F}}+\frac{1}{n} \log C_{\mathrm{e}}$

where $q_{\mathrm{e}}(\mathrm{mg} / \mathrm{g})$ represents the amount of phosphate adsorbed on the solid zirconium-pillared adsorbent and $C_{e}(\mathrm{mg} / \mathrm{L})$ is the concentration of phosphate solution at equilibrium. $Q^{0}(\mathrm{mg} / \mathrm{g})$ is the monolayer adsorption capacity, and $b(\mathrm{~L} / \mathrm{mg})$ is the energy of adsorption. $K_{\mathrm{F}}$ is the Freundlich constant, and $n$ represents the intensity of adsorption. The value of $b$ and $Q^{0}$ is obtained from the plot $C_{\mathrm{e}} / q_{\mathrm{e}}$ versus $C_{\mathrm{e}}$ (Fig. 3a). The value for $K_{\mathrm{F}}$ and $n$ is obtained from the $\log q_{\mathrm{e}}$ versus $\log C_{\mathrm{e}}$ (Fig. 3b). The favorability of the adsorption is represented by the equilibrium parameter $R_{\mathrm{L}}$ [47]:

$R_{\mathrm{L}}=\frac{1}{1+b C_{0}}$

where $b$ is the Langmuir constant and $C_{0}$ is the initial concentration of phosphate solution. The favorability of the adsorption process is represented in the order $0<R_{\mathrm{L}}<1$.

Table 3 shows the higher regression coefficient $\left(R^{2}>0.97\right)$ for Langmuir isotherm indicating the suitability of the model in explaining the adsorption of phosphate onto pillared clay. As temperature rises (15 to $\left.35^{\circ} \mathrm{C}\right), Q^{0}$ value $(27.03$ to $35.71 \mathrm{mg} / \mathrm{g}$ ) also increases confirming the endothermic nature. The increase in $b$ value ( 0.09 to 0.17 ) with the rise in temperature conveys the strength and affinity of the clay surface towards phosphate species as reported elsewhere [48]. The values of $R_{\mathrm{L}}$ were found to be between 0 and 1 for the various initial concentrations of phosphate (15-100 mg/L) confirming the favorability of the adsorption of phosphate species onto adsorbent [49]. A comparative study on phosphate adsorption using ZPBC and other modified bentonite clay minerals is presented in Table 4 and found that ZPBC prepared by the novel method is a better adsorbent than reported.

The spontaneity and feasibility of the adsorption process were studied using thermodynamic parameters (free energy $\Delta G^{0}$; enthalpy $\Delta H^{0}$; entropy $\Delta S^{0}$ ) at optimized conditions $\mathrm{pH} 3.0$, temperatures 15,25 and $35^{\circ} \mathrm{C}$, adsorbent dose $2.0 \mathrm{~g} / \mathrm{L}$ and various initial phosphate
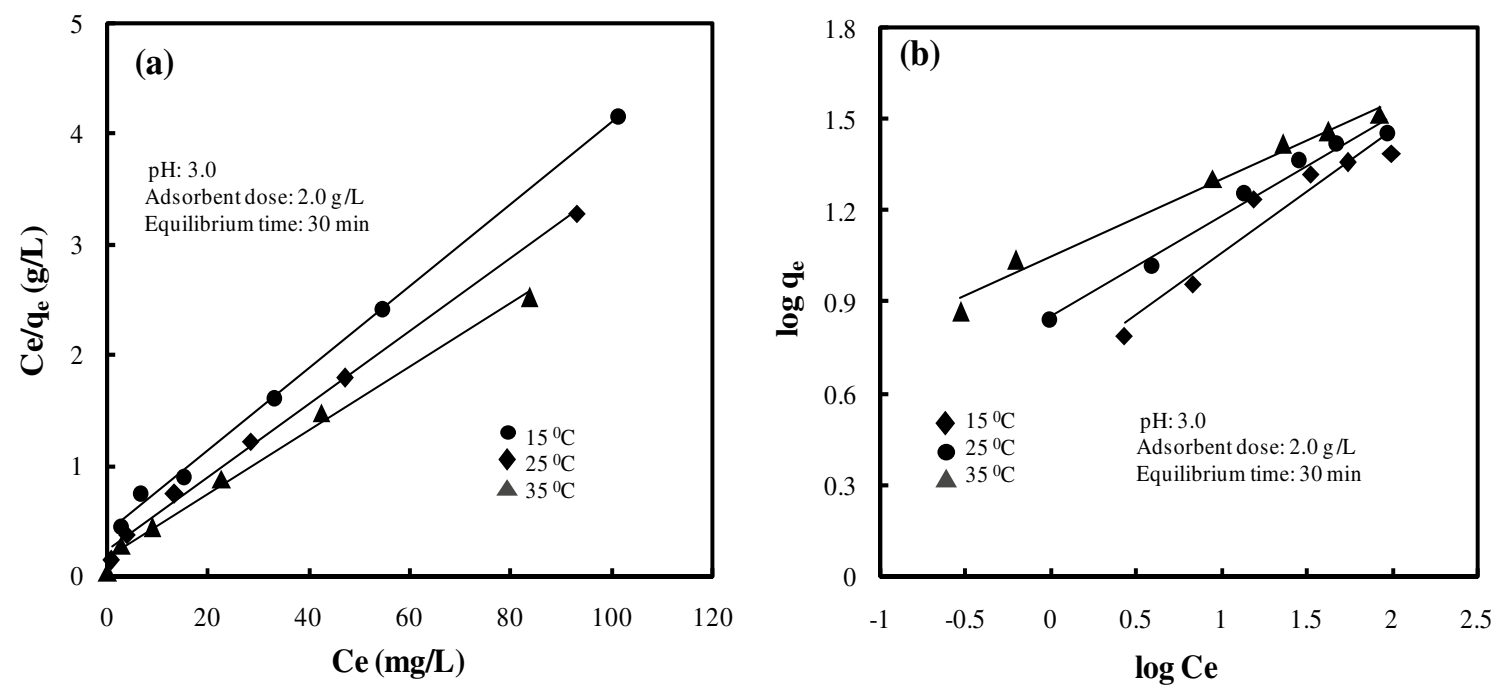

Fig. 3 a Langmuir, b Freundlich isotherm plots for the adsorption of phosphate onto ZPBC 
Table 4 Comparison of adsorption capacity using various modified bentonite adsorbents for the removal of phosphate studies

\begin{tabular}{lcclllll}
\hline Adsorbent & $Q^{0}(\mathrm{mg} / \mathrm{g})$ & $\mathrm{pH}$ & Temp $\left({ }^{\circ} \mathrm{C}\right)$ & $\begin{array}{l}\text { Adsorbent } \\
\text { dose }(\mathrm{g} / \mathrm{L})\end{array}$ & Time $(\mathrm{min})$ & Conc: $(\mathrm{mg} / \mathrm{L})$ & References \\
\hline Zenith/Fe & 11.15 & 7.0 & 25 & 0.4 & 120 & $0.05-5$ & {$[55]$} \\
Al-Bent & 12.70 & 3.0 & - & 4.0 & 360 & $25-60$ & {$[56]$} \\
Fe-Bent & 11.20 & 3.0 & - & 4.0 & 360 & $25-60$ & {$[56]$} \\
Al-ABn & 12.87 & 5.0 & 25 & 2.0 & 360 & $2-60$ & {$[48]$} \\
Al-ABn-AB & 11.11 & 5.0 & 25 & 2.0 & 720 & $2-60$ & {$[48]$} \\
NT-25La & 14.00 & 6.0 & 25 & 0.75 & 60 & $0.5-80$ & {$[57]$} \\
Bephos ${ }^{\mathrm{TM}}$ & 26.5 & 7.0 & 25 & 0.4 & 30 & $0.05-20$ & {$[58]$} \\
ZrNaBT & 7.25 & 7.0 & 25 & 1.0 & 1440 & $2-35$ & {$[59]$} \\
ZPBC & 30.30 & 3.0 & 25 & 2.0 & 30 & $15-100$ & Present work \\
ZPBC & 35.71 & 3.0 & 35 & 2.0 & 30 & $15-100$ & Present work \\
\hline
\end{tabular}

concentrations $15,25,50$ and $100 \mathrm{mg} / \mathrm{L}$. The relationship between these parameters is represented by the following equations:

$\Delta G^{0}=-R T \ln K_{0}$

$\ln K_{0}=\frac{\Delta S^{0}}{R}-\frac{\Delta H^{0}}{R T}$

$\Delta G^{0}$ is the Gibb's free energy in $\mathrm{kJ} / \mathrm{mol}, R$ is the universal gas constant $(R=8.314 \mathrm{~J} / \mathrm{mol} / \mathrm{K})$ and $T$ is the absolute temperature in Kelvin. The equilibrium constant $k_{0}$ is calculated from the plot of $\ln q_{\mathrm{e}} / C_{\mathrm{e}}$ versus $q_{\mathrm{e}}$ and extrapolating to zero at three different temperatures. The value of $\Delta H^{0}$ $(\mathrm{kJ} / \mathrm{mol})$ and $\Delta S^{0}(\mathrm{~J} / \mathrm{mol} / \mathrm{K})$ was calculated from the slope

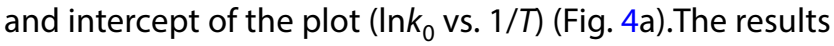
obtained are shown in Table S2. The value obtained for $\Delta G^{0}(-0.909,-2.428,-3.328 \mathrm{~kJ} / \mathrm{mol})$ is negative indicating the spontaneity of the adsorption process [18]. The value obtained for $\Delta G^{0}(<-20 \mathrm{~kJ} / \mathrm{mol})$ indicates the importance of electrostatic interaction followed by surface complexation on phosphate adsorption onto pillared clay [50]. The positive value for $\Delta \mathrm{H}^{0}(38.24 \mathrm{~kJ} / \mathrm{mol})$ gives an idea that adsorption occurs by the endothermic process, and also the positive value for $\Delta S^{0}(133.52 \mathrm{~J} / \mathrm{mol} / \mathrm{K})$ indicates that there is an increase in randomness and also the affinity of phosphate ions towards the adsorbent surface. A similar observation was obtained for modified bentonite for the removal of the anionic pollutant from the aqueous phase $[51,52]$.

\subsection{Application of the adsorbent into the riverine system}

The efficiency of the adsorbent (ZPBC) for the removal of phosphate was confirmed by the real sample analysis of
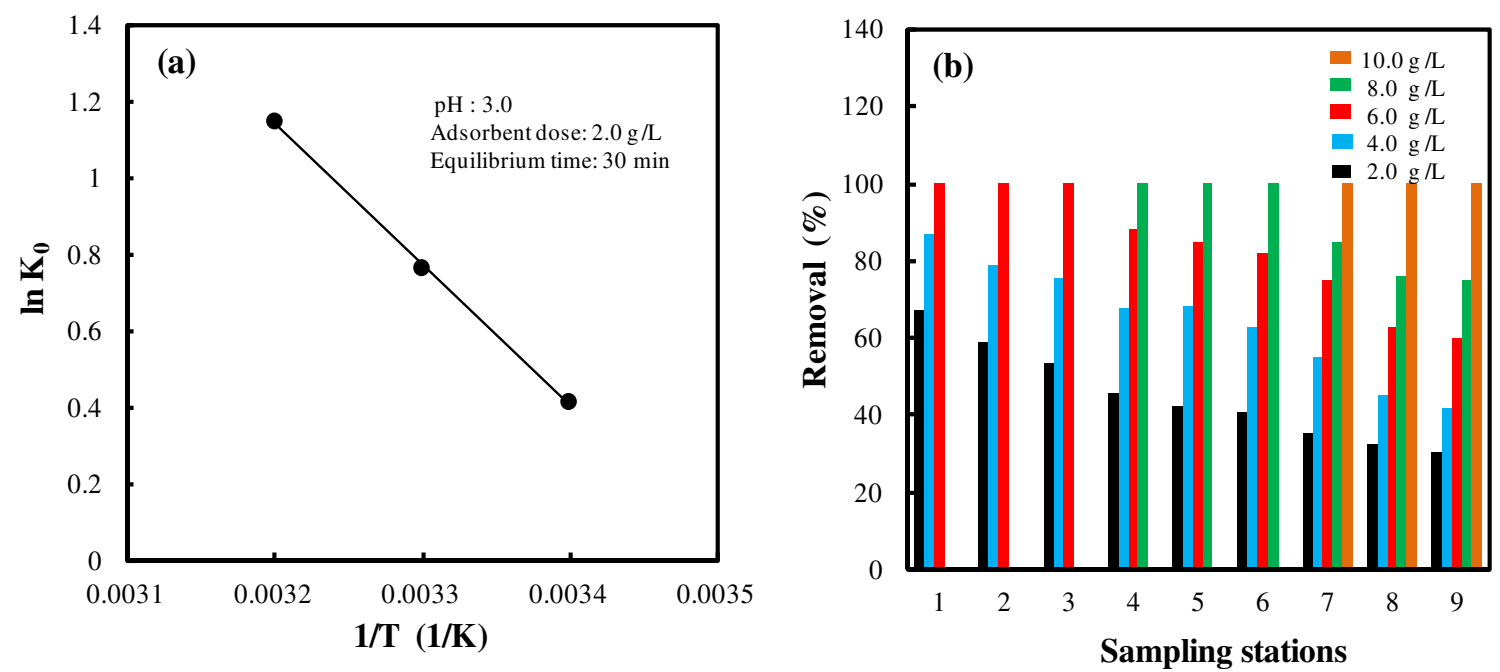

Fig.4 a Plot of $\ln K_{0}$ versus 1/T for the adsorption of phosphate onto ZPBC, $\mathbf{b}$ effect of adsorbent dosage for the removal of phosphate species from Trivandrum urban area water samples by ZPBC [experimental conditions: contact time 30 min, temperature $30^{\circ} \mathrm{C}$ ] 
riverine samples collected from nine stations. The composition of water samples is depicted in Table 1. The optimized conditions such as contact time (30 min), temperature $\left(30^{\circ} \mathrm{C}\right)$ and initial concentration $(15 \mathrm{mg} / \mathrm{L})$ were confirmed from the batch adsorption experiments. The $\mathrm{pH}$ of the solution was not adjusted (the same $\mathrm{pH}$ reported during fieldwork). The phosphate solution was spiked $13.02,12.44,12.73,11.32,11.16$ and $9.08 \mathrm{mg} / \mathrm{L}$, respectively, for the water samples from stations 1 to 6 , and the collected water samples as such were used for the remaining stations. The effects of adsorbent dose (2.0, 4.0, 6.0, 8.0 and $10.0 \mathrm{~g} / \mathrm{L}$ ) were studied and are shown in Fig. $4 \mathrm{~b}$. It is evident from the figure that as the dosage amount increases the percentage removal of phosphate increases and almost complete removal of phosphate was obtained by using different dosages for different samples. Almost 99.9\% phosphate removal was obtained for stations 1 to 3,4 to 6 and 7 to 9 using $6.0,8.0$ and $10.0 \mathrm{~g} / \mathrm{L}$ of the adsorbent.

\subsection{WQI calculation after ZPBC treatment}

The adsorbent-treated surface water samples were taken for the analysis of various physico-chemical parameters mentioned in WQI calculation, and the result obtained is shown in Table S3. The values obtained by WQI calculation for the ZPBC-treated surface water samples are as follows: 42.79 (station 1), 50.51 (station 2), 52.16 (station 3), 72.14 (station 4), 75.58 (station 5), 98.74 (station 6), 200.65 (station 7), 204.3 (station 8) and 256.65 (station 9). The values obtained are very lower when compared to WQI calculated for adsorbent untreated riverine sample (Table 2). This indicates that after treating with the adsorbent, a tremendous change in the quality of water has occurred. It was also found from Table S3, the anionic species that has been removed almost $99.9 \%$ from the adsorbent-treated surface water sample was phosphate. Before adsorbent treatment, the concentration of phosphate ions present in stations 1 to 9 was 1.98, 2.56, 2.27, $3.68,3.84,5.92,15.02,17.34$ and $20.54 \mathrm{mg} / \mathrm{L}$. But after treating with $\mathrm{ZPBC}$, for stations 1 to $3 ; 0.005 \mathrm{mg} / \mathrm{L}$, stations 4 to $6 ; 0.006,0.007,0.007 \mathrm{mg} / \mathrm{L}$, and for stations 7 to $9 ; 0.007 \mathrm{mg} / \mathrm{L}$ of phosphate ions are only remaining in the water sample. This highlights the efficiency of ZPBC in removing phosphate ions from the surface water. This resulted in the tremendous decrease in WQI values. Another factor that promoted the decrease in WQI to a small extent is as follows: It is clear from Table $\mathrm{S} 3$ that the concentration of $\mathrm{SO}_{4}{ }^{2-}, \mathrm{NO}_{3}{ }^{-}-\mathrm{N}$ and $\mathrm{NH}_{4}{ }^{+}-\mathrm{N}$ also varied. The slight decrease in the concentration of these anions follows the order: $\mathrm{SO}_{4}{ }^{2-}>\mathrm{Cl}^{-}>\mathrm{NO}_{3}{ }^{-}-\mathrm{N}$. The selectivity of an adsorbent towards a particular ions in the presence of other ions depends on the type of interaction formed by the competing ions on the surface of the adsorbent. Phosphate ions are tetrahedral and form both inner and outer complexes with the adsorbent, and also zirconiumpillared clays have a high affinity towards phosphate species. Sulphate ions form inner sphere complex only to a small extent with the adsorbent, and as a result a slight decrease in concentration of $\mathrm{SO}_{4}{ }^{2-}$ ions from the adsorbent-treated water sample occurred. Also, the availability of different forms of phosphate species $\left(\mathrm{H}_{2} \mathrm{PO}_{4}{ }^{-}\right.$and $\left.\mathrm{HPO}_{4}{ }^{2-}\right)$ in the adsorbent-treated water also makes the adsorbent more selective towards phosphate than sulphate ions. There are also other cationic species in the water, such as $\mathrm{Ca}^{2+}$ and $\mathrm{Mg}^{2+}$, which can also influence phosphate adsorption. The binding of these ions can enhance phosphate adsorption by making the surface of the adsorbent more electropositive or by forming intermediate ternary complexes [20]. Other ions like $\mathrm{Cl}^{-}$and $\mathrm{NO}_{3}{ }^{-}-\mathrm{N}$ form outersphere complexes (weaker interactions) with the adsorbent, and as a result the concentration of $\mathrm{Cl}^{-}$and $\mathrm{NO}_{3}{ }^{-} \mathrm{N}$ present in surface water slightly decreases, water quality increases and WQI decreases. The decrease in concentration of ammonium ions in adsorbent-treated riverine samples may be due to the conversion of ammonium to nitrate or by exchange with the interlayer cations of the adsorbent. A very small change in the concentration of DO occurred during the experiment, but it is not responsible for bringing down the WQI values. The values of $\mathrm{pH}$ also slightly decreased during adsorbent treatment onto surface water samples. The $\mathrm{pH}$ values after ZPBC treatment were within the surface standard limit of 6.5-9.2. The values for TDS were slightly decreased due to the adsorption of the anions and cations onto the adsorbent. Even though the values of EC and TDS for the adsorbenttreated water decreased, they are not within the surface water standard limit. This proves that ZPBC is a very good selective adsorbent for the removal of phosphate species from wastewaters. By using the adsorbent, the concentration of phosphate anions can be brought below $0.1 \mathrm{~g} / \mathrm{L}$ (surface water standard); thereby, the eutrophic condition of the riverine system can be minimized to an extent. But some of the cations and anions present in the adsorbent-treated surface water samples are still above surface water standard limit. The decrease in WQI value after treatment with the pillared clay was mainly due to phosphate removal. For the domestic use of the riverine water, the concentration of these anions and cations has to be reduced. Thus, it is proved that our lowcost and eco-friendly adsorbent ZPBC is very efficient for the selective adsorption of phosphate, and in future, the investigated materials can be applied in the field in 
order to construct permeable reactive barriers (PRBs) for phosphate removal in real conditions.

\subsection{Design of single-stage batch reactor}

The mathematically modelled equations from kinetic and isotherm studies can be used for optimizing the stages in the single-stage batch reactor $[38,53]$. In this study, the single-stage batch reactor is designed by using Langmuir isotherm data of phosphate ions. The main purpose of the design is to reduce the phosphate solution from an initial concentration $C_{\mathrm{o}}$ to $C_{\mathrm{t}}(\mathrm{mg} / \mathrm{L})$ in a phosphate solution containing $V(\mathrm{~L})$ of water. At the same time when $W(\mathrm{~g})$ of ZPBC is added, there is a change in phosphate ion solution from $q_{0}$ to $q_{t}$. The mass balance equation for the removal of the phosphate ions from the aqueous phase to that loaded on the surface of the adsorbent is given by

$\left(C_{0}-C_{t}\right) V=\left(q_{t}-q_{0}\right) W$.

At equilibrium conditions, $q_{0}=0, C_{t}=C_{\mathrm{e}}, q_{t}=q_{\mathrm{e}}, C_{t}=C_{\mathrm{e}^{\prime}}$ Eq. (13) becomes

$\frac{W}{V}=\frac{C_{0}-C_{e}}{q_{e}}$.

From (8), $q_{\mathrm{e}}=\frac{Q^{0} b C_{\mathrm{e}}}{1+b C_{\mathrm{e}}}$. Substituting it in Eq. 14, we obtain

$\frac{W}{V}=\frac{\left(C_{0}-C_{\mathrm{e}}\right)\left(1+b C_{\mathrm{e}}\right)}{Q^{0} b C_{\mathrm{e}}}$.

Substituting Langmuir constants $Q^{0}=30.30$ and $b=0.15$ (298 K) from Table 4, then Eq. (15) becomes

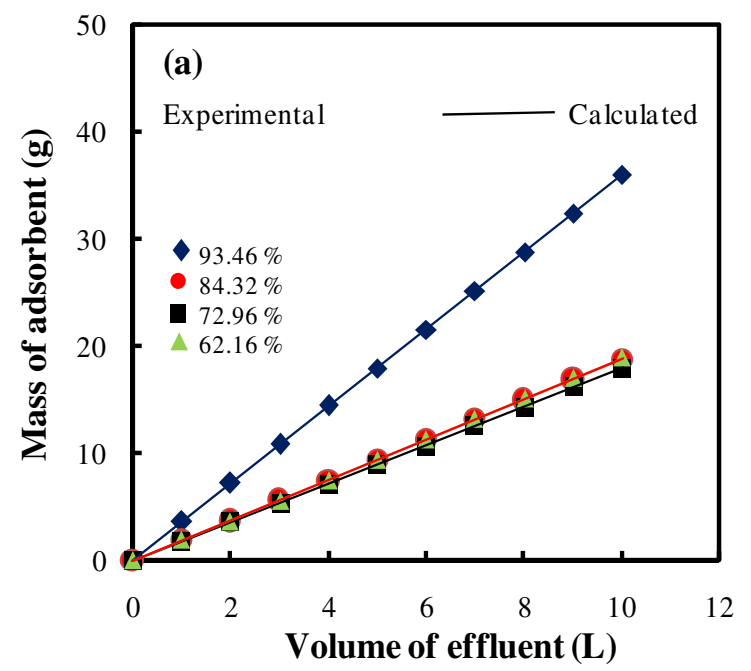

$\frac{W}{V}=\frac{\left(C_{0}-C_{\mathrm{e}}\right)\left(1+0.15 C_{\mathrm{e}}\right)}{4.545 C_{\mathrm{e}}}$

From Eq. (16), the mass of ZPBC required to achieve $93.46,84.32,72.96$ and $62.16 \%$ removal by treating the definite volume of phosphate ion-containing effluent having an initial concentration $C_{0}(15,25,50,75,100 \mathrm{~mL})$ can be calculated. The theoretical and experimental mass of ZPBC versus different volumes of effluent for different percentages of removal of phosphate is depicted in Fig. 5 a. Also, the experimental and theoretical mass of adsorbent versus different initial concentrations and different volumes for the adsorption of phosphate ions from aqueous solutions is shown in Fig. 5b. Similar works for the development of a single-stage reactor are reported by other researchers [54].

\subsection{Desorption studies and cost estimation of the adsorbent}

The desorption capacity of the adsorbent determines its economic value for the mitigation of phosphate species from real water samples. The concentrations of $\mathrm{Na}_{2} \mathrm{CO}_{3}$ were varied from 0.005 to $0.1 \mathrm{M}$ and found that by using $0.025 \mathrm{M} \mathrm{Na}_{2} \mathrm{CO}_{3}$ maximum phosphate was desorbed from ZPBC within $3 \mathrm{~h}$. The adsorption-desorption experiment was carried out for five cycles using $0.025 \mathrm{M} \mathrm{Na}_{2} \mathrm{CO}_{3}$, and the results are shown in Fig. S2. After five cycles, the adsorption capacity of pillared clay declined from 92.6 to $77.5 \%$ and recovery of phosphate decreased from 90.6 to $75.3 \%$. The loss of the adsorbent during the five sorption cycles is found to be minimum, showing the capability of the pillared clay in batch reactor systems.

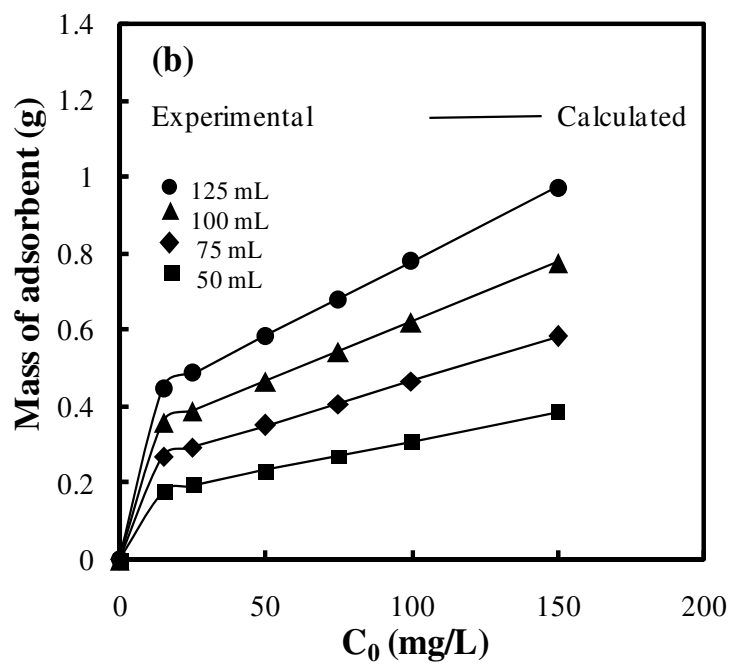

Fig. 5 a Mass of adsorbent ZPBC against different volumes for different percentage removal of phosphate ions and $\mathbf{b}$ mass of adsorbent ZPBC against different initial concentrations and different volumes for removal of phosphate ions from aqueous solutions 
The economic utility of the ZPBC-based adsorption system for the removal of phosphate from the riverine samples faces major challenges such as the availability of material from the local market, low cost, desorption capacity and performance of the adsorbent towards adsorbate. Therefore, its cost estimation is a significant part of the work. The precursor material, bentonite clay, was obtained from Gujarat Clay mines at a reduced price. The final cost of the material was in the range of $\$ 105-115$ per ton after calculating the expenses for the transport of the material, chemicals and electrical energy.

\section{Conclusions}

The various physico-chemical parameters such as $\mathrm{pH}, \mathrm{EC}$, TDS, DO, $\mathrm{Cl}^{-}, \mathrm{HCO}_{3}{ }^{-}, \mathrm{SO}_{4}{ }^{2-}, \mathrm{NO}_{3}{ }^{-}-\mathrm{N}, \mathrm{PO}_{4}{ }^{3-}-\mathrm{P}$ and $\mathrm{NH}_{4}{ }^{+}-\mathrm{N}$ of the riverine water of the Trivandrum urban area were analysed. WQI calculation using the surface water standards explores the eutrophic condition of the river basin. The concentration of phosphate anion ( $>0.1 \mathrm{mg} / \mathrm{L}$ ) in the surface water is found to be very high. The novel adsorbent ZPBC was successfully tested on a simulated phosphate solution with various initial concentrations such as 15, 25, 50 and $100 \mathrm{mg} / \mathrm{L}$. The kinetics of the adsorption was well fitted onto the pseudo-second-order model having a high regression coefficient (0.992). Langmuir isotherm model explained the monolayer adsorption of phosphate species onto ZPBC. Moreover, using this model single-stage batch reactor was designed from which the amount of ZPBC required to achieve $93.46,84.32,72.96$ and $62.16 \%$ removal of phosphate species was calculated. The effect of ZPBC dosage on river water samples also conducted experimentally under optimized conditions such as contact time $30 \mathrm{~min}$ and temperature $30^{\circ} \mathrm{C}$. It was observed that as the dosage amount increases from 6.0 to 8.0 almost $99.9 \%$ phosphate removal was achieved. The WQI values obtained after adsorbent treatment also emphasized the selectivity of the pillared clay for the removal of phosphate and also the enhancement of quality of surface water. Thus, ZPBC is a promising adsorbent for the successful removal of phosphate species from the aqueous environment.

Acknowledgements The authors are thankful to Dr. N. Purnachandra Rao, Director, NCESS, for providing the laboratory and knowledge resource facilities. The recently introduced instrumental facilities in Central Chemical Laboratory, NCESS, under the Ministry of Earth Sciences, Govt. of India, is also acknowledged.

\section{Compliance with ethical standards}

Conflict of interest The authors declare that they have no known competing financial interests or personal relationships that could have appeared to influence the work reported in this paper.

\section{References}

1. Oyekanmi AA, Ahmad A, Hossain K, Rafatullah M (2019) Adsorption of Rhodamine $B$ dye from aqueous solution onto acid treated banana peel: Response surface methodology, kinetics and isotherm studies. PLoS ONE 14(5):e0216878

2. Oyekanmi AA, Ahmad A, Hossain K, Rafatullah M (2019) Statistical optimization for adsorption of rhodamine $B$ dye from aqueous solutions. J Mol Liq 281:48-58

3. Ternes T, Joss A, Oehlmann J (2015) Occurrence, fate, removal and assessment of emerging contaminants in water in the water cycle (from wastewater to drinking water). Water Res 72:1-2

4. Lermontov A, Yokoyama L, Lermontov M, Machado MAS (2011) A fuzzy water quality index for watershed quality analysis and management. In: Broniewicz E (ed) Environmental management in practice. In Tech. Crotia, pp 387-410

5. Lumb A, Sharma TC, Bibeault JF (2011) A review of genesis and evolution of water quality index (WQI) and some future directions. Water Qual Expo Health 3:11-24

6. Fathi E, Ahmadmahmoodi RZ, Bidaki RZ (2018) Water quality evaluation using water quality index and multivariate methods, Beheshtabad River. Iran Appl Water Sci 8:210

7. Hou W, Sun S, Wang M, Li X, Zhang N, Xin X, Sun L, Li W, Jia R (2016) Assessing water quality of five typical reservoirs in lower reaches of Yellow River, China: using a water quality index method. Ecol Indic 61(2):309-316

8. Medeiros AC, Faial KRF, Faiala KCF, Lopes IDS, Lima MO, Guimaraes RM, Mendonca NM (2017) Quality index of the surface water of Amazonian rivers in industrial areas in Para, Brazil. Mar Pollut Bull 123(1):156-164

9. Mitra S, Ghosh S, Sathpathy KK, Bhatttacharya BD, Sarkar SK, Mishra P, Raja P (2018) Water quality assessment of the ecologically stressed Hooghly River estuary, India: A multivariate approach. Mar Pollut Bull 126:592-599

10. Pesce SF, Wunderlin DA (2000) Use of water quality indices to verify the impact of Cordoba city (Argentina) on Suquia River. Water Res 34(11):2915-2926

11. Monteagudo L, Moreno JL, Picazo F (2012) River eutrophication: irrigated vs. non-irrigated agriculture through different spatial scales. Water Res 46(8):2759-2771

12. Paerl HW, Scott JT, McCarthy MJ, Newell SE, Gardner W, Havens KE, Hoffman DK, Wilhelm SW, Wurtsbaugh WA (2016) It takes two to tango: When and where dual nutrient $(N \& P)$ reductions are needed to protect lakes and downstream ecosystems. Environ Sci Technol 50(20):10805-10813

13. Blecken G-T, Zinger $Y$, Deletic A, Fletcher TD, Hedstrom A, Viklander M (2010) Laboratory study on stormwater biofiltration: nutrient and sediment removal in cold temperatures. J Hydrol 394(3):507-514

14. Hao H, Wang Y, Shi B (2019) $\mathrm{NaLa}\left(\mathrm{CO}_{3}\right)_{2}$ hybridized with $\mathrm{Fe}_{3} \mathrm{O}_{4}$ for efficient phosphate removal: synthesis and adsorption mechanistic study. Water Res 155:1-11

15. Correll DL (1998) The role of phosphorus in the eutrophication of receiving waters: a review. J Environ Qual 27:261-266

16. Su Yu, Cui H, Qi Li, Gao S, ShangJ K (2013) Strong adsorption of phosphate by amorphous zirconium oxide nanoparticles. Water Res 47(14):5018-5026

17. Ahmad A, Mohd-Setapara SH, Chuoa SC, Khatoon A, Wani WA, Kumar R, Rafatullah M (2015) Recent advances in new generation dye removal technologies: novel search of approaches to reprocess wastewater. RSC Adv 5:30801-30818

18. Li Z, Qiu Z, Yang J, Ma B, Lu S, Qin C (2018) Investigation of phosphate adsorption from an aqueous solution using spent fluid catalytic cracking catalyst containing lanthanum. Front Environ Sci Eng 12(6):15 
19. Ahmad A, Rafatullah M, Vakili M, Mohd-Setapar SH (2018) Equilibrium and kinetic studies of methyl orange adsorption onto chemically treated oil palm trunk powder. Environ Eng Manag J 17:2933-2943

20. Kumar PS, Korving L, Keesman KJ, van Loosdrecht MCM, Witkamp GJ (2019) Effect of pore size distribution and particle size of porous metal oxides on phosphate adsorption capacity and kinetics. Chem Eng J 358:160-169

21. Chinoune K, BentalebK BZ, Nadim A, Maschke U (2016) Adsorption of reactive dyes from aqueous solution by dirty bentonite. Appl Clay Sci 123:64-75

22. Zhu L, Zhu R (2007) Simultaneous sorption of organic compounds and phosphate to inorganic-organic bentonites from water. Sep Purif Technol 54(1):71-76

23. Mahadevan H, Krishnan KA, Pillai RR, Sudhakaran S (2019) Stirring-ageing technique to develop zirconium-pillared bentonite clay along with its surface profiling using various spectroscopic techniques. Res Chem Intermed. https://doi. org/10.1007/s11164-019-03982-2

24. APHA (2005) Standard methods for the examination of water and wastewater, 21 st edn. APHA, AWWA, WEF, Washington

25. Eljabi N, Caissie D, Turkkan N (2014) Water quality index assessment under climate change. J Water Resour Prot 6:533-542

26. Mosley LM, Daly R, Palmer D, Yeates P, Dallimore C, Biswas T, Simson SL (2015) Predictive modelling of $\mathrm{pH}$ and dissolved metal concentrations and speciation following mixing of acid drainage with river water. Appl Geochem 59:1-10

27. Siddiqi SZ, Chandrasekhar SVA (2010) Hydrobiology of raw water reservoir at Adra, Purulia District, West Bengal. Rec Zool Surv India 110:83-91

28. Ren K, Pan X, Zeng J, Jiao Y (2017) Distribution and source identification of dissolved sulfate by dual isotopes in waters of the Babu subterranean river basin, SW China. J Radioanal Nucl Chem 312:317-328

29. Weber-Scannell PK, Duffy LK (2007) Effects of total dissolved solids on aquatic organisms: A review of literature and recommendation for salmonid species. Am J Environ Sci 3:1-6

30. Brandt MJ, Johnson KM, Elphinston AJ, Ratnayaka DD (2017) Chapter 7-chemistry, microbiology and biology of water. In: Twort's water supply, 7th ed, pp 235-321

31. Batrinescu G, Birsan E, Vasila G, Stanescu B, Stanescu E, Paun I, Petrescu M, Filot C (2011) Identification of the aquatic ecosystems integrating variables in the Suceava hydrographic basin and their correlations. J Environ Prot Ecol 12(4):1627-1643

32. Oelkers EH, Valsami-Jones E (2008) Phosphate mineral reactivity and global sustainability. Elements 4(2):83-87

33. Wafula MSM, Owuor PO, Kengara FO, Ofula AVO, Matano SA (2018) Influence of land use practices on water physicochemical parameters and nutrients loading along the Mara River of East Africa. Afr J Environ Sci Technol 12(7):235-243

34. Ramakrishnaiah CR, Sadashivaiah C, Ranganna G (2009) Assessment of water quality index for the groundwater in Tumkur taluk, Karnataka state, India. E-J Chem 6(2):523-530

35. Sener S, Davraz A, Karaguzel R (2013) Evaluating the anthropogenic and geologic impacts on water quality of the Egirdir Lake, Turkey. Environ Earth Sci 70:2527-2544

36. Zong E, Huang G, Liu X, Lei W, Jiang S, Ma Z, Wang J, Song $P$ (2018) A lignin-based nano-adsorbent for superfast and highly selective removal of phosphate. J Mater Chem A 6:9971

37. Tanyol M, Yonten V, Demir V (2015) Removal of phosphate from aqueous solutions by chemical- and thermal-modified bentonite clay. Water Air Soil Pollut 226:269

38. Ho YS, Mckay G (1999) Pseudo second order model for sorption processes. Process Biochem 34(5):451-465
39. Lagergren S (1898) About the theory of so-called adsorption of soluble substances. In: Kungliga Svenska Vetenskapsakademiens Handlingar, vol 24, pp 1-39

40. Tu YJ, You CF (2014) Phosphorus adsorption onto green synthesized nano-bimetal ferrites: equilibrium, kinetic and thermodynamic investigation. Chem Eng J 251:285-292

41. Deng L, Shi Z (2015) Synthesis and characterization of a novel $\mathrm{Mg}-\mathrm{Al}$ hydrotalcite-loaded kaolin clay and its adsorption properties for phosphate in aqueous solution. J Alloys Compd 637:188-196

42. Karimaian KA, Amrane A, Kazemian H, Panahi R, Zarrabi M (2013) Retention of phosphorous ions on natural and engineered waste pumice: characterization, equilibrium, competing ions, regeneration, kinetic, equilibrium and thermodynamic study. Appl Surf Sci 284:419-431

43. Langmuir I (1918) The adsorption of gases on lane surfaces of glass, mica and platinum. J Am Chem Soc 40(9):1361-1403

44. Freundlich HMF (1906) Uber dye adsorption in Losungen. Z Phys Chem 57:385-471

45. Bouraie ME, Masoud AA (2017) Adsorption of phosphate ions from aqueous solution by modified bentonite with magnesium hydroxide $\mathrm{Mg}(\mathrm{OH})_{2}$. Appl Clay Sci 140:157-164

46. Mwamulina T, Zhang X, Wang Y, Song S, Peng C (2018) Novel approach to control adsorbent aggregation: iron fixed bentonite-fly ash for lead $(\mathrm{Pb})$ and cadmium $(\mathrm{Cd})$ removal from aqueous media. Front Environ Sci Eng 12(2):2

47. Hall KR, Eagleton LC, Acrivos A, Vermeulen T (1966) Pore and solid diffusion kinetics in fixed-bed adsorption under constant pattern conditions. Ind Eng Chem Fundam 5(2):212-223

48. Pawar RR, Gupta P, Lalhmunsiama BHC, Lee SM (2016) Al-intercalated acid activated bentonite beads for the removal of aqueous phosphate. Sci Total Environ 572:1222-1230

49. Molavi H, Pourghaderi A, Shojaei A (2019) Experimental study on the influence of initial $\mathrm{pH}$, ionic strength, and temperature on the selective adsorption of dyes onto nanodiamonds. J Chem Eng Data 64(4):1508-1514

50. Weng CH, Tsai CZ, Chu SH, Sharma YC (2007) Adsorption characteristics of copper(II) onto spent activated clay. Sep Purif Technol 54(2):187-197

51. Ma J, Qi J, Yao C, Cui B, Zhang T, Li D (2012) A novel bentonitebased adsorbent for anionic pollutant removal from water. Chem Eng J 200:97-103

52. Markou G, Inglezakis VJ, Mitrogiannis D, Efthimiopoulos I, Psychoyou M, Koutsovitis P, Muylaert K, Baziotis I (2016) Sorption mechanism(s) of orthophosphate onto $\mathrm{Ca}(\mathrm{OH})_{2}$ pretreated bentonite. RSC Adv 6(27):22295-22305

53. Anirudhan TS, Rijith S, TharunA R (2010) Adsorptive removal of thorium (IV) from aqueous solutions using poly (methacrylic acid)-grafted chitosan/bentonite composite matrix: Process design and equilibrium studies. Colloids Surf A Physicochem Eng Asp 368(1):13-22

54. Basu S, Ghosh G, Saha S (2018) Adsorption characteristics of phosphoric acid induced activation of bio-carbon: equilibrium, kinetics, thermodynamics and batch adsorber design. Process Saf Environ Prot 117:125-142

55. Zamparas M, Gianni A, Stathi P, Deligiannakis Y, Zacharias I (2012) Removal of phosphate from natural waters using innovative modified bentonites. Appl Clay Sci 62:101-106

56. Yan LG, Xu YY, Yu HQ, Xin XD, Wei Q, Du B (2010) Adsorption of phosphate from aqueous solution by hydroxy-aluminum, hydroxy-iron and hydroxy-iron-aluminum pillared bentonites. J Hazard Mater 179:244-250

57. Kuroki V, Bosco GE, Fadini PS, Mozeto AA, Cestari AR, Carvalho WA (2014) Use of a La(III)-modified bentonite for effective phosphate removal from aqueous media. J Hazard Mater 274:124-131 
58. Zamparas M, Drosos M, Georgiou Y, Deligiannakis Y, Zacharias I (2013) A novel bentonite-humic acid composite material Bephos ${ }^{\mathrm{TM}}$ for removal of phosphate and ammonium from eutrophic waters. Chem Eng J 225:43-51

59. Lin J, Jiang B, Zhan Y (2018) Effect of pre-treatment of bentonite with sodium and calcium ions on phosphate adsorption onto zirconium-modified bentonite. J Environ Manage 217:183-195
Publisher's Note Springer Nature remains neutral with regard to jurisdictional claims in published maps and institutional affiliations.

\section{SN Applied Sciences}

